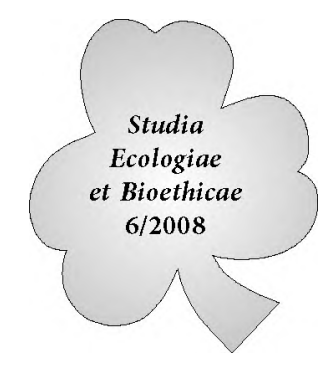

\title{
Działania Muzeum Pałac w Wilanowie dla zrównoważonego rozwoju
}

\begin{abstract}
Wstęp
Celem artykułu jest ukazanie Muzeum Pałac w Wilanowie jako ośrodka kultury w kontekście zrównoważonego rozwoju. Z tej racji, po krótkim przedstawieniu określeń zrównoważonego rozwoju oraz zaprezentowaniu statutu Muzeum Pałac w Wilanowie, wskazane zostaną trzy obszary aktywności tej placówki kulturowej. Wiele spośród nich wpisuje się w ideę zrównoważonego rozwoju.

W artykule zostaną omówione trzy obszary takich działań, na podstawie których możemy mówić o zrównoważonym rozwoju w placówce kulturowej. Pierwszym z nich jest misja edukacyjna prowadzona przez Muzeum, w którą szczególny wkład ma także autor artykułu i studenci Instytutu Ekologii i Bioetyki UKSW. Drugi obszar zainteresowań tej placówki - omówiony w tekście - odnosi się do kwestii rozwoju dzielnicy Wilanów (najbliższego otoczenia Pałacu), dla której Muzeum jest aktywnym partnerem dbającym o zachowanie zasad zrównoważonego rozwoju. Ostatnim obszarem działań Muzeum, wpływających na ekorozwój, są działania własne inicjowane i podejmowane przez samo Muzeum.
\end{abstract}

\section{Zrównoważony rozwój w dokumentach}

Jednym z najczęściej powtarzanych określeń zrównoważonego rozwoju jest sformułowanie określające go jako rozwój z zachowaniem potrzeb gospodarczych, społecznych i środowiskowych. Początkowo opisywany i rozumiany był tylko w perspektywie ekonomii. Rozumiano go wówczas jako taki rozwój społeczno-gospodarczy, który uwzględnia w procesach gospodarowania uwarunkowania ekologiczne $e^{1}$ W literaturze funkcjonuje także wiele innych definicji tego terminu, co powoduje trudności ze zrozumieniem idei zrównoważonego rozwoju. Wieloznaczność definicji, jak i samej idei prowadzi także do różnorodnego określania tej idei, jak np.: zrównoważony rozwój, trwały rozwój, ekorozwój².

\footnotetext{
D. KieŁczowski, O pojęciu trwałego rozwoju, Studia ecologiae et bioethicae 1(2003), s. 347.

Więcej na ten temat zobacz w: A. PAPUzIŃski, Filozoficzne aspekty zrównoważonego rozwoju - wprowadzenie, Problemy ekorozwoju 2 (2006), s. 25-32.
} 
Z powodów wyżej wymienionych, w celu sprecyzowania idei zrównoważonego rozwoju proponuję odwołać się do prawa polskiego. Zdaje się, iż ujęcie formalno-prawne może być bardzo pomocne w usystematyzowaniu definicji tej idei. I tak, prawo ochrony środowiska w artykule trzecim określa zrównoważony rozwój jako taki rozwój społeczno-gospodarczy, w którym nastęuje proces integrowania działań, politycznych, gospodarczych i społecznych, z zachowaniem równowagi przyrodniczej oraz trwałości podstawowych procesów przyrodniczych, w celu zagwarantowania możliwości zaspokojenia podstawowych potrzeb poszczególnych społeczności lub obywateli zarówno wspótczesnego pokolenia, jak i przyszlych po$k o l e n^{3}$. Krótszą i bardziej przejrzystą definicję na potrzeby niniejszej pracy odnaleźć można w Narodowej Strategii Ram Odniesienia 2007-2013. Zrównoważony rozwój - orientacja na poprawe jakości życia obecnych i przyszlych pokoleń, przy zapewnieniu ochrony $i$ zachowania zasobów przyrodniczych $i$ dziedzictwa kulturowego oraz właściwej struktury demograficznej społeczeństwa ${ }^{4}$. Natomiast w Deklaracji z Johannesburga w sprawie zrównoważonego rozwoju podpisanej 4 września 2002 r. uwaga została zwrócona na naszą odpowiedzialność w kwestiach zrównoważonego rozwoju. (...) przyjmujemy na siebie zbiorową odpowiedzialność za dokonanie dalszego postępu w zakresie wspótzależnych i nawzajem wspierających się filarów zrównoważonego rozwoju - rozwoju gospodarczego, rozwoju społecznego i ochrony środowiska - i ich wzmacniania na szczeblu lokalnym, krajowym, regionalnym i globalnym ${ }^{5}$. Na podstawie powyższej definicji spotkać można powszechnie cytowane diagramy przedstawiające trzy filary zrównoważonego rozwoju.

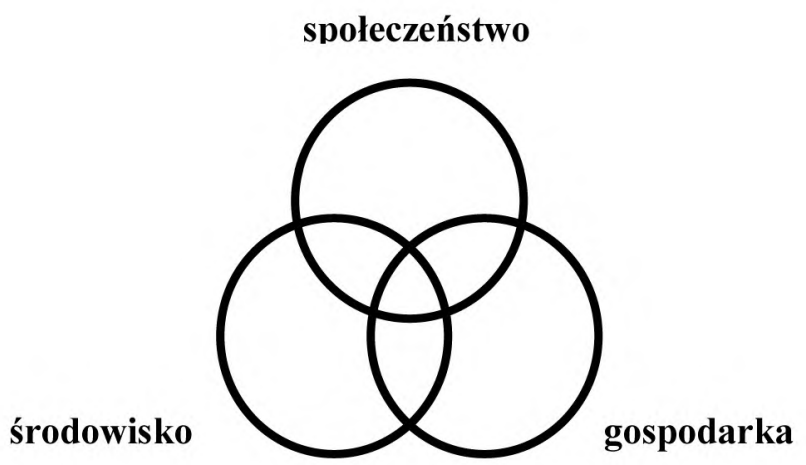

Rys. 1. Trzy filary zrównoważonego rozwoju - opracowanie własne

Prawo ochrony środowiska 27 kwietnia 2001 Dz.U. 2001 Nr. 62, poz. 627 z późn, zm. Art. 3.

Narodowa Strategia Ram Odniesienia 2007-2013.

5 Deklaracja $z$ Johannesburga w sprawie zrównoważonego rozwoju, podpisana 4 września 2002. 
Zatem, na zrównoważony rozwój składają się trzy filary: gospodarczy, społeczny i środowiskowy. Z punktu widzenia ośrodka kultury podział ten może wyglądać nieco inaczej. Bowiem przyroda jest fundamentem kultury ${ }^{6}$, również dziedzictwo kulturowe warunkuje istnienie dziedzictwa przyrodniczego ${ }^{7}$. A więc, jeśli mamy na myśli środowisko przyrodnicze zmienione przez człowieka i przyrodę kształtowaną przez człowieka, filar społeczny i środowiskowy będą tożsame. W takim razie, filarami zrównoważonego rozwoju dla ośrodka kultury będą dwa - filar gospodarczy i filar dziedzictwa kulturowego.

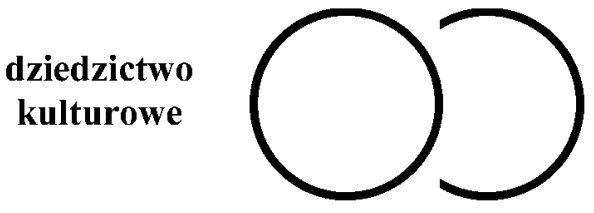

gospodarka

Rys. 2. Dwa filary zrównoważonego rozwoju-opracowanie wlasne.

Idea zrównoważonego rozwoju pojawia się w szeregu dokumentów. Zwraca się w nich uwagę także na obowiązek wdrażania i realizowania zasady zrównoważonego rozwoju ${ }^{8}$. W dokumencie Polska 2025 - Długookresowa strategia trwałego i zrównoważonego rozwoju znajduje się zapis: (...) cel nadrzędny zakłada określony paradygmat ładu społecznego, opartego na poszanowaniu praw człowie$k a$, akceptacji wartości rodziny i solidaryzmu wewnatrz- i międzypokoleniowego, realizacji zasady subsydiarności i dbałości o wspólne dobro, o tożsamość narodowa i suwerennośc .

Ośrodek kultury, jakim jest Muzeum Pałac w Wilanowie, również stara się realizować swoje zadania $w$ duchu zrównoważonego rozwoju. Przesłanki potwierdzające to założenie można odnaleźć już w statucie Muzeum Pałac w Wilanowie. W artykule 5 wskazano, że celem działania Muzeum jest zachowanie dla przyszłych pokolen dziedzictwa kulturowego, jakim jest zabytkowa rezydencja w Wilanowie z jej historyczną kolekcja muzealiów, pozyskanymi zbiorami oraz istniejacymi w granicach instytucji $i$ ich sasiedztwie zabytkowymi obiektami bu-

6 Więcej na ten temat zobacz w G. BöHme, Filozofia i estetyka przyrody w dobie kryzysu środowiska naturalnego, Warszawa 2002, oraz J. KoLBuszowski, Ochrona przyrody a kultura, Wrocław 1992.

7 Cytat pochodzi z wykładu Ochrona przestrzeni rolniczej J. Sadowskiego, który odbył się w Instytucie Ochrony Przyrody, Kraków 30.05.2008.

8 Więcej o obowiązku moralnym człowieka zobacz w: Z. Piątek, Etyka środowiskowa. Nowe spojrzenie na miejsce człowieka w przyrodzie, Kraków 1998.

9 Polska 2025 - Długookresowa strategia trwalego i zrównoważonego rozwoju. 
dowlanymi, ogrodami i parkami z historycznym wystrojem artystycznym $i$ wyposażeniem technicznym ${ }^{10}$. W statucie tym ukazują się nam dwie ważne kwestie. Pierwsza to chęć zachowania dla przyszlych pokoleń całego dziedzictwa kulturowego. Nie tylko kolekcję muzealną, ale także przyrodę ogrodów i parków, a więc świat przyrodniczy. Drugą ważną kwestią zapisaną w statucie jest chęć zachowania dziedzictwa kulturowego nie tylko w granicach tej instytucji, ale także w jej sąsiedztwie. Dziedzictwo kulturowe, a co za tym idzie i cała różnorodność kulturowa, jest również bardzo ważnym czynnikiem kształtującym zrównoważony rozwój. Potwierdzenie tych słów można odnaleźć w Konwencji UNESCO w sprawie ochrony i promowania różnorodności form wyrazu kulturowego podpisanej 20.10.2005 r. w Paryżu. Artykuł 2 tej konwencji zawiera zasadę trwałego i zrównoważonego rozwoju mówiącą iż, różnorodność kulturowa jest wielkim bogactwem jednostek $i$ społeczeństw. Ochrona, promowanie $i$ zachowanie różnorodności kulturowej są podstawowym warunkiem trwałego i zrównoważonego rozwoju dla dobra obecnych i przyszlych pokoleñ ${ }^{11}$.

\section{Obszary działalności Muzeum Pałac w Wilanowie}

Muzeum Pałac w Wilanowie nie ogranicza się jedynie do zapisywania w dokumentach postanowień idei zrównoważonego rozwoju. Podejmuje szereg zadań, które można zaliczyć do realizowania tychże postanowień. Wszystkie działania w niniejszej pracy zostały podzielone na trzy obszary: misję edukacyjną, działania Muzeum jako partnera $w$ rozwoju dzielnicy oraz działania inicjowane przez samo Muzeum.

\subsection{Edukacja}

Działalność edukacyjna jest jednym z najważniejszych elementów zrównoważonego rozwoju ${ }^{12}$. Muzeum Pałac w Wilanowie podejmuje szereg inicjatyw edukacyjnych, które mają przybliżyć turystom całe dziedzictwo kulturowe Wilanowa. Misję edukacyjną Muzeum realizuje między innymi poprzez lekcje tematyczne, weekendy rodzinne, czy też imprezy plenerowe. Przekazywanie wiedzy odbywa się również dzięki takim przekazom wiedzy jak ścieżki edukacyjne. Najciekawszym rozwiąaniem dydaktycznym dla zrównoważonego rozwoju wydaje się ścieżka przyrodniczo-historyczna. Integracja traktowanych uprzednio oddzielnie obszarów problematycznych ma jeszcze jeden istotny aspekt edukacyjny ${ }^{13}$.

\footnotetext{
Statut Muzeum Pałac w Wilanowie.

11 Konwencja UNESCO w sprawie ochrony i promowania różnorodności form wyrazu kulturowego 20.10.2005 Paryż, Art. 2.

12 Więcej informacji w dokumencie Dekada dla zrównoważonego rozwoju.

13 A. PAWŁowski, Ścieżki dydaktyczne jako element edukacji dla zrównoważonego rozwoju, Filozoficzne i społeczne uwarunkowania zrównoważonego rozwoju 16 (2003), s. 155.
} 
Opracowane dla Muzeum Pałac w Wilanowie ścieżki dydaktyczne opisują zarówno świat przyrody, jak i historię miejsca. \ym samym spełniają one założenia ich funkcji dla zrównoważonego rozwoju formułowane przez A. Pawłowskiego - to znaczy że, dobrze by było, aby nie ograniczaly się one jedynie do świata przyrody, ale uwzględnialy takż płaszczyznę historyczna i kulturowa. Dopiero wtedy ich znaczenie edukacyjne dla zrównoważonego rozwoju będzie petne ${ }^{14}$.

Na szczególną uwagę $\mathrm{w}$ tym miejscu zasługuje program edukacyjny o nazwie „badacze przyrody” realizowany w parku wilanowskim Muzeum Pałac w Wilanowie przy współpracy Uniwersytetu Kardynała Stefana Wyszyńskiego. Jest to program skierowany do dzieci i ich rodziców. Spotkania odbywały się w każdy weekend kwietnia i maja 2008 roku w godzinach 10.00-14.00. Celem tego programu jest szerzenie wśród uczestników wiedzy o przyrodniczych elementach Wilanowa i jego historycznej i kulturowej wartości. Każde z dziewięciu spotkań było poświęcone innej tematyce: zwiastuny wiosny, zwierzyniec, ptasiowo, owady, motyle, drzewa i krzewy, kwiaty, woda, finał. Spotkania w parku wilanowskim odbywały się w dwóch formach. Pierwszą, były spotkania pod namiotem, gdzie były ustawione stoliki z krzesełkami dla dzieci. Najmłodsi goście mogli w tym miejscu atrakcyjnie spędzić czas malując, kolorując i wyklejając określone rysunki. Starsze dzieci rozwiązywały zagadki w formie krzyżówek, układanek czy wykreślanek i labiryntów. Wszystkie zaś chętnie brały udział w zabawach zręcznościowych takich, jak wypychanie maskotek w kształcie ptaków, konstruowanie własnych drzew, czy filtrowanie zabrudzonej wody. Zabawom w namiocie towarzyszyły prezentacje multimedialne poświęcone poszczególnym tematycznym spotkaniom. Wszystkie zajęcia pod namiotem prowadzili studenci II roku ochrony środowiska UKSW w ramach swoich zajęć terenowych z edukacji ekologicznej. Służyli oni swoją wiedzą i byli pomocni w rozwiązywaniu poszczególnych zadań. Drugą formą realizacji programu „badacze przyrody” były wycieczki z przewodnikami po parku wilanowskim. $Z$ tej formy edukacji najchętniej korzystały całe rodziny oraz grupy zorganizowane odwiedzające pałac i przy okazji park wilanowski. Podczas wycieczek zainteresowani spacerowicze mogli się dowiedzieć o wszystkich ciekawostkach dotyczących terenu Wilanowa. Osoby oprowadzające po parku wilanowskim odpowiadały na wszystkie pytania zainteresowanych turystów. 囚ak zorganizowane spotkania, podczas programu „badacze przyrody", zachęcily do skorzystania z tych zajęć dużej liczby osób. O spełnieniu roli programu może świadczyć obecność rodzin, które cyklicznie przychodziły na kolejne spotkania oraz wszystkich osób, które przyjechały do Wilanowa z wycieczką i odchodziły zadowolone.

14 冈amże, s. 157. 


\subsection{Współpraca $\mathrm{z}$ miastem}

Drugim obszarem działalności Muzeum Pałac w Wilanowie dla zrównoważonego rozwoju jest działalność Muzeum jako partnera w rozwoju dzielnicy. Współpraca ta odbywa się w trzech głównych obszarach: zagospodarowania przestrzennego, ochrony zabytków i ochrony środowiska. Aktywność Muzeum w tym obszarze realizowana jest w głównej mierze w stałym kontakcie z władzami centralnymi i samorządowymi Warszawy.

Zagospodarowanie przestrzenne jest bardzo ważnym czynnikiem w rozwoju całej dzielnicy Wilanów. Dla Muzeum Pałac w Wilanowie zagospodarowanie przestrzenne jest istotną kwestią ze względu między innymi na historyczne osie widokowe. Osie, które pozostały na terenie Wilanowa, są bardzo narażone na zniszczenie w czasie wielkich inwestycji budowlanych. Obecnie nadal jest odczuwany brak spójności w zagospodarowaniu przestrzennym otoczenia rezydencji wilanowskiej wynikający głównie z dużej dowolności odczytywania tychże planów. Przykładem braku dobrego planu zagospodarowania przestrzennego uwzględniającego uwarunkowania kulturowe jest zgoda na zajęcie pól wilanowskich ścisłą zabudową miejską typu osiedlowego, która niszczy dotychczasowy ład przestrzenny. Innym zagrożeniem jest brak planów zagospodarowania przestrzennego dla Morysina i Folwarku Wilanowskiego znajdujących się w sąsiedztwie rezydencji wilanowskiej. \worzy to bezpośrednie zagrożenie dla Muzeum wynikające $z$ negatywnego oddziaływania ewentualnych inwestycji deweloperskich na rezydencję wilanowską. Naturalne osie widokowe, które wyznaczają np. wody powierzchniowe Wilanowa, również są zagrożone. \u pojawia się problem z odtworzeniem Kanału Królewskiego na osi Pałacu w Wilanowie. Innym przykładem osi widokowej, która jest obecnie nieczytelna, to oś znajdująca się między Pałacem a bramą w Morysinie ${ }_{2}$ którą wyznaczać powinny szpalery drzew. Obecnie oś ta jest zarośnięta przez drzewa.

Ochrona zabytków jest szczególnie ważna ze względu na zachowanie tożsamości miejsca. Przede wszystkim, na uwagę w tym miejscu zasługują zabytkowe budowle, którym należy się ochrona. Zdaje się najlepszym sposobem jest ochrona prawna, w myśl ustawy o ochronie zabytków i opiece nad zabytkami ${ }^{15}$. Przewiduje ona cztery formy ochrony zabytków: wpis do rejestru zabytków, uznanie za pomnik historii, utworzenie parku kulturowego i ustalenie ochrony w miejscowym planie zagospodarowanie przestrzennego. Na terenie samego Muzeum Pałac w Wilanowie i jego okolicy możemy spotkać zarówno indywidualne obiekty wpisane do rejestru zabytków, jak i całe obszary objęte tym rejestrem np. „Wilanów- założenie urbanistyczne”. Na terenie Wilanowa od 1994 roku znajduje się także druga forma ochrony zabyt-

15 Dz.U. 2003 nr 162 poz. 1568 US冈AWA z 23 lipca 2003 r. o ochronie zabytków i opiece nad zabytkami, Art. 7. 
ków, jakim jest Pomnik Historii. Na zrealizowanie kolejnej formy ochrony z ustawy, jaką jest utworzenie parku kulturowego, cały czas czeka Muzeum Pałac w Wilanowie. Mimo, iż Rada Miasta Stołecznego Warszawy wyraziła zamiar powołania projektowanego Wilanowskiego Parku Kulturowego, nie ma ostatecznej decyzji o powołaniu tej formy ochrony. Natomiast o kłopotach z ustaleniem micjscowego planu zagospodarowania przestrzennego korzystnego dla Muzeum Pałac w Wilanowie, mowa była we wcześniejszej części pracy. Wydaje się jednak, iż obecny stan prac nad ochroną zabytków nie jest wystarczający. Potwierdzenie tego stanu rzeczy odzwierciedla się w aktywnych działaniach Muzeum zmierzających do poprawy ochrony zabytków. Prace te dotyczą zarówno dodawania do rejestru kolejnych zabytków, jak i promowania korzystnych zapisów w miejscowych planach zagospodarowania przestrzennego. Nie można w tym miejscu zapomnieć o roli, jaką odgrywa Muzeum Pałac w Wilanowie w tworzeniu Wilanowskiego Parku Kulturowego.

Ochrona środowiska jest istotnym czynnikiem decydującym o stanie środowiska przyrodniczego na terenie Wilanowa. Na widoczną niestety degradację ekosystemu parku wilanowskiego i jego okolic składa się wiele czynników. Najbardziej powszechnymi zagrożeniami dla świata przyrody są: zanieczyszczenia wody i obniżenie lustra wody, zabudowa okolicznych terenów, zanieczyszczenia powietrza, a co za tym idzie - usychanie drzew i zanikanie siedlisk wielu zwierząt i roślin. Największa ilość zanieczyszczeń do parku trafia wraz z wodami Potoku Służewieckiego. Potok ten zbiera wody opadowe z $10 \%$ powierzchni całego miasta, przede wszystkim z Ursynowa. Wody potoku są często zanieczyszczane substancjami ropopochodnymi, metalami ciężkimi i okresowo podczas zim solami i płynami służącymi do odmrażania i odśnieżania ulic. Wszystkie zanieczyszczenia splywają i osadzają się na dnie jeziora Wilanowskiego ${ }^{16}$. Wpływa to zaś negatywnie na cały ekosystem wodny Wilanowa. Problem potoku zajmuje się Muzeum Pałac w Wilanowie, jednak bez zaangażowania Marszałka Województwa i Miasta stołecznego Warszawy prace nad poprawą stanu jakości wód nie mogą być rozwiązane. Prócz stanu czystości wody na terenie Wilanowa równie istotnym czynnikiem jest także obniżanie się poziomu wód gruntowych. Zjawisko to występuje głównie wskutek licznych inwestycji budowlanych w okolicy Wilanowa, dla których prowadzone są odwodnienia terenu. Opadanie wód gruntowych wpływa także na spadek ilości wody we wszystkich wodach powierzchniowych. Stan czystości wody i jej miejscowy niedobór oddziałuje na stare drzewa rosnące w Parku Wilkanowskim, które usychają ${ }^{17}$. Nowym zagro-

${ }^{16}$ Jeziorko Wilanowskie jest usytuowane w dawnym starorzeczu Wisły, a jego naturalne położenie stanowi element kompozycyjny założenia pałacowo-parkowego Wilanowa.

17 Deficyt wody i obniżenie zwierciadła wody dotyczy głównie starych drzew: dębów, lip, jesionów, wiązów oraz klonów. Drzewa posiadające rozwinięty już system korzeniowy dopasowany do poziomu wód gruntowych, nie są w stanie zmienić swojego układu korzeniowego, w wyniku czego drzewa te są osłabione i mniej odporne na susze letnie, choroby oraz szkodniki. 
żeniem dla Muzeum Pałac w Wilanowie może stać się Południowa Obwodnica Warszawy. Według założeń planistycznych, wody opadowe z tej drogi mają być odprowadzane do jeziora Wilanowskiego. Prócz potencjalnego zagrożenia dla środowiska płynącego z tej inwestycji, zagrożone są wartości krajobrazowe tego miejsca.

Przy okazji programu edukacyjnego „badacze przyrody”, wśród dorosłych osób odwiedzających park i biorących udział w zajęciach przeprowadzona została ankieta, w której znalazło się pytanie: Co według Państwa, jest zagrożeniem dla Parku Wilanowskiego? Wśród moźliwych odpowiedzi znalazły się propozycje: czystość wody w jeziorze i potoku, niedobór wody i usychanie drzew, zanieczyszczenia powietrza, zabudowa okolicznych terenów, zanikanie siedlisk, inne, park nie jest zagrożony. Osoby biorące udział w ankiecie dostrzegały wszystkie wymienione wyżej propozycje. Najpopularniejszą odpowiedzią i zarazem największym zagrożeniem, w oczach turystów, jest problem zabudowy okolicznych terenów. 冈en wybór może wskazywać zaniepokojenie osób ankietowanych, niebezpieczeństwem utraty charakteru Parku Wilanowskiego i jego otoczenia. Drugim najczęściej podawanym zagrożeniem dla parku, według osób ankietowanych, jest zanieczyszczenie powietrza. Natomiast na czwartym i piątym miejscu znajdują się problemy dotyczące wody. Najpierw dostrzeżona została kwestia czystości wody w Jeziorze Wilanowskim i w Potoku Służewieckim. Natomiast po zanieczyszczeniach wód uplasował się zaobserwowany niedobór wody i w konsekwencji usychanie drzew w Parku.

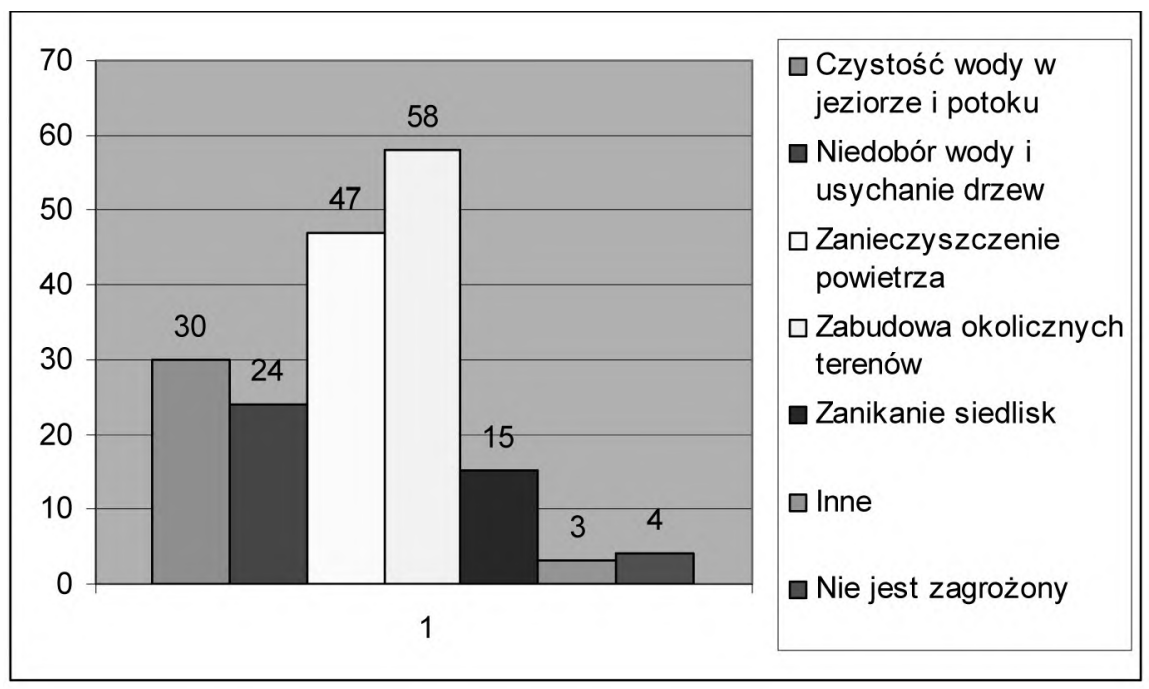

Rys. 3. Możliwe zagrożenia dla Parku Wilanowskiego z liczbą głosów na poszczególne odpowiedzi-opracowanie wlasne. 


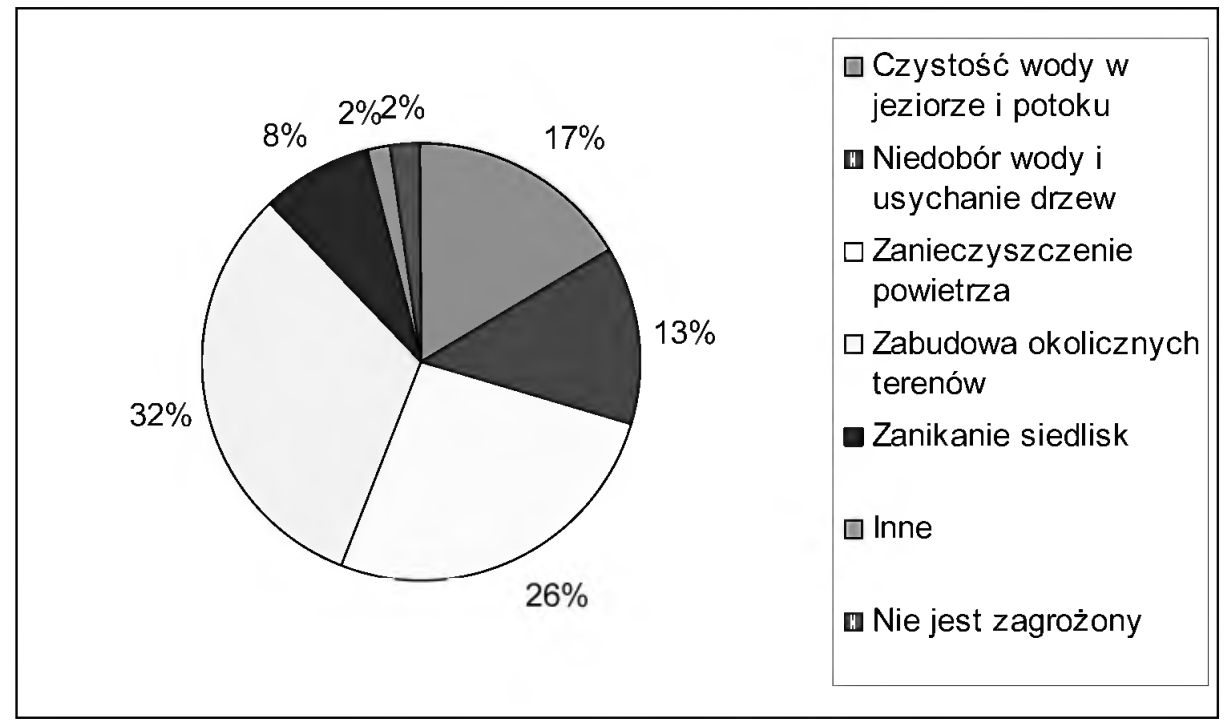

Rys. 4. Diagram przedstawiajacy procentowe wyniki ankiety - opracowanie własne.

\subsection{Inicjatywy Muzeum}

Ostatnim obszarem podejmowanych działań przez Muzeum Pałac w Wilanowie dla zrównoważonego rozwoju są wszelkie działania inicjowane przez samo Muzeum $^{18}$. Ważnym zagadnieniem w podejmowaniu działań dla zrównoważonego rozwoju jest dbanie przez Muzeum o tożsamość miejsca. 冈ak zwane genius loci rezydencji królewskiej powstało z inicjatywy króla Jana III Sobieskiego, który harmonijnie powiązał kulturę i naturę. Kompozycja pałacowo-ogrodowa z czasem się zmieniała o nowe założenia parkowo-krajobrazowe. Niestety obecnie trudno jest odczytać całą kompozycję poza ternem Muzeum. Nie są już dostrzegalne kompozycje krajobrazowe z Natolinem, Ursynowem czy Gucinem. Opisywane powyżej inwestycje budowlane zagrażają ostatnim założeniom kompozycyjnym jak np. ląki zalewowe znajdujące się w pobliżu Pałacu.

Obecnie na 90 hektarach znajdują się - prócz bogatej przyrody, historycznych założeń parkowo-ogrodowych - także 32 zabytkowe budowle. Niestety nie jest jeszcze wystarczająco szczegółowo opisana cała historia Parku i Pałacu Wilanowskiego. Dlatego Muzeum Pałac w Wilanowie prowadzi szereg prac i badań archeologicznych, architektonicznych oraz konserwatorskich. Analiza wszystkich badań prowadzonych przez Muzeum jest złożona i długotrwała.

18 W miejscu tym pomijam działalność Muzeum Pałac w Wilanowie - wcześniej opisaną - polegającą na wymianie korespondencji z władzami na szczeblu centralnym i samorządowym w celu zachowania i poprawy stanu dziedzictwa kulturowego na terenie Wilanowa. 
Wszystkie zebrane informacje są niezbędne do dobrego zarządzania historycznym miejscem i utrzymania charakteru miejsca. Jedynie w ten sposób można poznać tożsamość i tradycję takiego ośrodka kultury.

Innym sposobem na zachowanie tożsamości miejsca zdaje się być inicjatywa powołania klubu dyskusyjnego „Pochwała inteligencji w Wilanowie” przy współpracy z Kolegium Wigierskim. Koncepcja wymiany myśli sięga czasów Jana III Sobieskiego, który inicjował dyskusje, badania naukowe, a także wspierał inicjatywy kulturotwórczą. Stanisław Kostka Potocki również wpisał się w ten nurt, zaś $\mathrm{z}$ jego inicjatywy powstało muzeum $\mathrm{w}$ Wilanowie. $\mathrm{Z}$ działalności poprzednich gospodarzy Wilanowa oraz $\mathrm{z}$ tożsamości miejsca zrodziło się przeświadczenie o potrzebie utworzenia klubu dyskusyjnego. Celem spotkań klubu jest dyskusja i wymiana myśli o genius loci Wilanowa. Każde spotkanie jest poświęcone innemu zagadnieniu. W efekcie spotkań poszukuje się odpowiedzi na pytania o dziedzictwo kulturowe Wilanowa, a także o wyzwania stawiane w obecnym czasie przed Muzeum Pałac w Wilanowie we wszystkich sferach jego działalności i funkcji jako ośrodka kultury.

Muzeum Pałac w Wilanowie również w duchu idei zrównoważonego rozwoju organizuje szereg konferencji naukowych. Jedną z nich była konferencja zorganizowana wspólnie z Uniwersytetem Kardynała Stefana Wyszyńskiego w październiku 2007 roku pod tytułem Wychowanie dla zrównoważonego rozwoju. Odbyła się w sali uczt. Podczas dwóch sesji naukowych zgromadzeni goście wskazali na istotny czynnik w wychowaniu zgodnym z ideą zrównoważonego rozwoju, jakim jest aspekt edukacyjny. Świadomość młodych ludzi w zakresie przyrody i kultury jest bowiem ważna ze względu na dobre rozumienie dziedzictwa kulturowego Wilanowa. Spotkania te wpisują się w potrzebne inicjatywy Muzeum.

\section{Podsumowanie}

Rozważając rolę działań dla zrównoważonego rozwoju, często pierwszym problemem staje się szukanie odpowiedzi na podstawowe pytanie o definicję i sens zrównoważonego rozwoju. W kontekście tym można się spotkać z wieloma zarzutami wobec tej idei. Najwyraźniej przedstawia to zagadnienie prof. W. Sztumski w swoich pracach pisząc, że idea zrównoważonego rozwoju, ze względu na kłopoty z realizacją, petni rolę swoistego mitu - jednego $z$ wielu innych mitów, jakimi karmi się współczesne społeczeństwo. Przede wszystkim dlatego, że u jej podstaw leży w większej mierze myślenie życzeniowe niż praktyczne ${ }^{19}$. Jednak według zasady, „myśl globalnie - działaj lokalnie”, można wprowadzać w życie ideę zrównoważonego rozwoju. Jedynym warunkiem jest dobra wola, zrozumienie

19 W. Szumski, Idea zrównoważonego rozwoju a możliwości jej urzeczywistnienia, Problemy ekorozwoju 2(2006), s. 75. 
samej idei, oraz chęć osób decydujących o realizacji przyjętych postanowień. Przykładem tego twierdzenia jest działalność Muzeum Pałac w Wilanowie, realizowanego w trzech opisanych wyżej obszarach: misji edukacyjnej, działań Muzeum jako partnera w rozwoju dzielnicy oraz działań inicjowanych przez samo Muzeum.

\title{
Activities in favour of sustainable development undertaken by Wilanow Palace Museum
}

\author{
SUMMARY
}

The article presents Wilanow Palace Museum as a centre of culture in the context of sustainable development. After giving an outline of definition related to sustainable development and presenting the statute of this institution, the article introduces fields of Museum's activities that are connected with the idea of sustainable development. These activities included conducting educational mission, supporting authorities of the Wilanow in maintaining sustainable development of Wilanow district and efforts undertaking by Wilanow Palace Museum on its own initiative. 